\title{
Mapping potential distribution of slender loris subspecies in peninsular India
}

\author{
Honnavalli N. Kumara ${ }^{1}$, Mohammed Irfan-Ullah ${ }^{2,4, *}$, Shanthala Kumar ${ }^{3}$ \\ ${ }^{1}$ National Institute of Advanced Studies, Bengaluru (Bangalore), Karnataka, India \\ ${ }^{2}$ Ecoinformatics Centre, Ashoka Trust for Research in Ecology and the Environment (ATREE), 659, 5th-A Main Road, Hebbal, \\ Bengaluru (Bangalore), Karnataka, 560 024, India \\ ${ }^{3}$ Kumaragiri, Lakshmisha Nagara, Main Road, Chikmagalur 577 101, India \\ ${ }^{4}$ Present address: Risk Management Solutions Inc. (RMSI), A-7 Sector 16, Noida, Uttar Pradesh 201 301, India
}

\begin{abstract}
The present study mapped the potential geographic distribution of subspecies of slender loris Loris lydekkerianus from peninsular India. We utilized occurrence records of more than 300 confirmed sightings of slender lorises to model the species' potential geographic distribution by applying an ecological niche modeling (ENM) framework using a desktop genetic algorithm for ruleset prediction (GARP) algorithm. Results indicate that the modeled potential distribution of a morphologically different and hitherto undescribed subspecies of slender loris is noticeably different in geographic space from the 2 known subspecies found within peninsular India. The potential geographic distribution of this subspecies appears to occupy a distinct and intermediate climate region running along the eastern fringe of the southern Western Ghats. Among the 2 known subspecies, the modeled potential distribution of L. 1. lydekkerianus corresponds with a relatively drier climate, largely occupying deciduous and open-scrub forest types, whereas the modeled potential distribution of L. l. malabaricus corresponds with wetter climates, ranging from deciduous to evergreen forest types. The presence of an undescribed subspecies of slender loris demonstrates an urgent need for a detailed exploration within the range modeled by the present study.
\end{abstract}

KEY WORDS: Ecological niche modeling $\cdot$ Loris lydekkerianus lydekkerianus $\cdot$ Loris lydekkerianus malabaricus · Primates · Western Ghats · Desktop GARP

\section{INTRODUCTION}

Information on species distribution patterns is crucial for effective conservation and management of biodiversity (Margules \& Pressey 2000). Given the alarming situation of extreme habitat alterations due to human activities, it is important to accurately assess the distribution and conservation status of threatened species to prevent future loss of global biodiversity. Substantial emphasis has been given to developing an objective quantitative framework to help managers and decision makers estimate and contain the rate of biodiversity loss by 2010 (Balmford et al. 2005). In order to meet such challenges, the IUCN Red List was used as an important tool to assess the status of global biodiversity (Baillie et al. 2004). It is argued that the Red List index can be used as a guide to judge whether or not the 2010 targets will be met (Butchart et al. 2004). However, some $9.4 \%$ or 3580 species could not be assessed accurately because of insufficient information (Baillie et al. 2004). For species allocated to this data deficient category, it is important to generate information on their distribution, abundance, habitat requirements and associated threats so that a manageable conservation strategy is identified before they reach the brink of extinction.

Assessing the status and patterns of distribution of arboreal mammals is a challenge, especially when they are cryptic, shy, nocturnal, lesser-known, secretive and, therefore, difficult to detect. However, it is essential to more precisely determine the distribution of these spe- 
cies in the wild, particularly when they are threatened by deforestation, habitat fragmentation and exploitation (Kinnaird et al. 2003, Linkie et al. 2006). Slender lorises constitute one such group of lesser-known arboreal mammals. Slender (Loris) and slow (Nycticebus) lorises are the only 2 known strepsirrhine primate genera reported from India. Slow lorises are known to occur in northeast India and parts of southeast Asia, while slender lorises are restricted to southern India and Sri Lanka (Roonwal \& Mohnot 1977, Nekaris \& Bearder 2007). Slender lorises are small, often solitary and nocturnal and, consequently, poorly studied until the late 1990s, when research became more common; see, for example, studies of their distribution (Singh et al. 1999, 2000, Kumar et al. 2002, 2006, in press), behavior (Nekaris 2001, 2003, Radhakrishna \& Singh 2002a,b,c, 2004a,b) and ecology (Nekaris \& Rusmussen 2003, Kumara 2005). The slender lorises of India (Loris lydekkerianus lydekkerianus and L. 1. malabaricus) are accorded the status of near threatened in the IUCN Red List of threatened species, and at the national level they have been assigned the highest level of protection under Schedule I, Part I of the Indian Wildlife Protection Act, 1972. The current classification of slender lorises (Groves 2001) includes 2 species and 6 subspecies; among them only 1 species (L. lydekkerianus) with 2 subspecies (L. 1. lydekkerianus and L. 1. malabaricus) is reported from India. In contrast, in Sri Lanka L. lydekkerianus is represented by a further 2 subspecies (L. 1. grandis and L. 1. nordicus) and a second species is also present with 2 subspecies (L. tardigradus tardigradus and L. t. nycticeboides).

Loris lydekkerianus lydekkerianus is known to occur in drier forests of Eastern Ghats, south of the River Godavari, and L. 1. malabaricus is reported from the wetter forests of Western Ghats, south of the River Tapti (Roonwal \& Mohnot 1977, Groves 2001, Nekaris \& Bearder 2007). Schulze \& Meier (1995) constructed an approximate distribution map for slender loris subspecies in southern India based on the origins of museum specimens collected between 1889 and 1929 (Jenkins 1987), sight records, animal collection records (Blandford 1888, Ryley 1913, Wroughton 1917, Ramaswami \& Kumar 1962, Seth 1963, Swayamprabha \& Kadam 1980, Devaraj Sarkar et al. 1981, Johnson 1984, Manjula 1984, Sarma \& Kadam 1984, Rao 1994) and the area estimations of Osman-Hill (1933) and Fiedler (1956). No lorises were recorded from the locations reported by Devaraj Sarkar et al. (1981) during the repeat surveys conducted by Kumara et al. (2006). Kumara et al. (2006) discovered significant variation between the observed and the reported distribution, possibly due to the loss of natural habitat under growing anthropogenic pressure in recent times (Kumara \& Singh 2004, Schulze et al. 2005, Kumara 2007).
The results of Kumara et al. (2006) elicited the need for a renewed effort to map slender loris distribution. Mapping the distribution in its entirety by means of ground surveys remains a prohibitively expensive and time-consuming task. The conventional approaches are also subjective and biased towards accessible or well-sampled areas, and could rarely be extended to remote and poorly known locations. Modern attempts as applied in the US gap analysis program (Csuti 1996) are data intensive, difficult to implement, heterogeneous and unreliable in the absence of extensive field checks (Peterson 2005). We therefore used the alternatives proposed by Peterson et al. (2003), Peterson \& Kluza (2003), and Peterson (2005), combining the known occurrence records from extensive field surveys and the construction of ecological niche models (ENM) to establish the potential distribution of slender lorises.

The ecological niche of a species is defined as the set of ecological conditions within which it is able to maintain populations without immigration (Grinnell 1917, Holt \& Gaines 1992). Several approaches have been used to approximate ecological niches (Nix 1986, Austin et al. 1990, Walker \& Cocks 1991, Manel et al. 1999b, Berry et al. 2002, Scott et al. 2002, Phillips et al. 2004); of these, one that has been widely tested in a broad range of applications is the genetic algorithm for rule-set prediction (GARP), which includes several inferential approaches in an iterative, evolutionarycomputing environment (Stockwell \& Peters 1999). ENMs have been useful in various ecological applications (Miller 1994, Csuti 1996, Tucker et al. 1997, Gottfried et al. 1999, Manel et al. 1999a,b), including recent applications to gap analysis (Peterson \& Kluza 2003, Peterson 2005).

Here we attempt to produce potential distribution maps of different subspecies of Loris lydekkerianus using an ENM framework for planning future surveys for systematic scientific sampling. These maps provide valuable biogeographical information that may help targeting surveys to accelerate the discovery of unknown populations and species (Raxworthy et al. 2003, Bourg et al. 2005). It is important to note that these maps identify regions that have similar environmental conditions where the species currently maintain populations, and should not be interpreted as the actual limits of the range of a species.

\section{MATERIALS AND METHODS}

The present study is an attempt to predict the potential distribution of different subspecies of slender loris in India using the DesktopGarp (www.nhm.ku.edu/ desktopgarp/) implementation within the openMod- 
eller Desktop (http://openmodeller.sourceforge.net/), a user-friendly interface to the GARP algorithm (Stockwell \& Noble 1992) for modeling the potential distribution of slender loris subspecies. We used 64 unique occurrence points of Loris lydekkerianus malabaricus, 58 of L. 1. lydekkerianus and all 13 of the undescribed subspecies L. l. ssp. ? obtained using equivalent methods within the states of Karnataka, Andhra Pradesh, Tamil Nadu and Kerala (Kumara 2005, 2007, Kumara et al. 2006).

There have been attempts (Stockwell \& Peterson 2002, Hernandez et al. 2006, Pearson et al. 2007) to establish the minimum sample size necessary for producing meaningful results using the ENM approach. The issue of sample size assumes greater importance especially in the case of rare species that suffer data deficiency by virtue of them being rare. Hernandez et al. (2006) found that accuracy of models was greater for species with small geographic ranges and limited environmental tolerances, which are the ecological characteristics of many rare species. Their results indicated that reasonable models could be made for some rare species, and they encouraged conservationists to resort to distribution modeling as a primary tool. One of the important reasons for modeling species distributions is to overcome the handicap of data deficiency, and ENM is particularly useful in such cases. A sample size of about 10 occurrence points could produce an average success rate of about $90 \%$ of the maximum success achieved by the best model; such models con- tribute to improved understanding of the species biogeography in the absence of first-hand sightings (Stockwell \& Peterson 2002, Hernandez et al. 2006, Pearson et al. 2007).

We used the monthly maximum normalized difference vegetation index (NDVI) $16 \mathrm{~d}$ composite images (2003) from the advanced very high resolution radiometer (AVHRR) satellite (Eidenshink \& Faundeen 1994). In addition, we noted elevation, slope, aspect and the compound topographic index (CTI) from the Hydro-1K dataset (USGS 2001) and included 19 bioclimatic variables (Hijmans et al. 2005) (P1 to P19, Table 1).

Sets of 100 model runs were developed for each analysis. In general, $25 \%$ of available occurrences were used for rule development (training data), $25 \%$ for rule selection and refinement (intrinsic testing data) and the remaining $50 \%$ occurrence points were set aside for an independent test and filter of the highest quality models (extrinsic testing data). To choose the best models from among the 100 replicates, we filtered models on the basis of omission and commission error estimates following recent recommendations (Anderson et al. 2003). Specifically, given the high quality occurrence data available, we selected 20 models presenting $0 \%$ omission based on the extrinsic testing data, and of these 20 , models falling in the central $50 \%$ of commission values were taken as the 10 best models.

To provide an independent validation of model performance, we prepared 4 replicates by randomly

Table 1. Parameters used for ecological niche modeling of Loris lydekkerianus sspp. Sr: serial number; CV: coefficient of variation

\begin{tabular}{|lll|}
\hline Sr & Parameter layer & Source \\
\hline 1 & Monthly normalized difference vegetation index (NDVI), 16 d composite from & Eidenshink \& Faundeen (1994) \\
& AVHRR satellite, January 2003 to December 2003 & \\
2 & Digital elevation model (DEM), slope, aspect and compound topographic index (CTI) & USGS (2001) \\
3 & P1-annual mean temperature & Hijmans et al. (2005) \\
4 & P2-mean diurnal range [mean(period max.-min.)] & Hijmans et al. (2005) \\
5 & P3-isothermality (P2/P7) & Hijmans et al. (2005) \\
6 & P4-temperature seasonality (CV) & Hijmans et al. (2005) \\
7 & P5-max. temperature of warmest period & Hijmans et al. (2005) \\
8 & P6-min. temperature of coldest period & Hijmans et al. (2005) \\
9 & P7-temperature annual range (P5-P6) & Hijmans et al. (2005) \\
10 & P8-mean temperature of wettest quarter & Hijmans et al. (2005) \\
11 & P9-mean temperature of driest quarter & Hijmans et al. (2005) \\
12 & P10-mean temperature of warmest quarter & Hijmans et al. (2005) \\
13 & P11-mean temperature of coldest quarter & Hijmans et al. (2005) \\
14 & P12-annual precipitation & Hijmans et al. (2005) \\
15 & P13-precipitation of wettest period & Hijmans et al. (2005) \\
16 & P14-precipitation of driest period & Hijmans et al. (2005) \\
17 & P15-precipitation seasonality (CV) & Hijmans et al. (2005) \\
18 & P16-precipitation of wettest quarter & Hijmans et al. (2005) \\
19 & P17-precipitation of driest quarter & Hijmans et al. (2005) \\
20 & P18-precipitation of warmest quarter & Hijmans et al. (2005) \\
21 & P19-precipitation of coldest quarter & Hijmans et al. (2005) \\
22 & Global land cover map & Hansen et al. (1998) \\
\hline
\end{tabular}


selecting a proportion of $75 \%$ occurrence points, setting aside the remaining $25 \%$ as validation points in each replicate for a completely independent test of predictive accuracy. Coincidence between independent testing points and model predictions was used as a measure of the model's predictive ability. Binomial tests based on the proportional area predicted and numbers of successfully and unsuccessfully predicted independent test points were used to compare observed predictive success with that expected under random (null) models of no association between predictions and test points. As model results are cumulative (in the form of a ramp of model agreement) from 0 (all models predict absence) to 10 (all models predict presence), we repeated tests across all thresholds (prediction levels 1 to 10).

We geographically intersected maps of potential distribution with environmental grids containing the spatial and temporal distribution of precipitation, temperature and elevation data to understand the partially sampled ecological niche within the regions of modeled distribution for each subspecies of slender loris.

We attempted to compare the forest type characteristics extracted from the locations known to be occupied by slender lorises and from the modeled potential distributions with the existing knowledge of the forest types described by Kumara et al. (2006). We geographically intersected the known locations and maps of potential distribution of slender loris subspecies with freely available global land cover maps (Hansen et al. 1998, 2000) and extracted information about the different land cover types (Table 1). For convenience, we provide the names of the land cover classes with their equivalents following the widely used descriptions of the forest types in India by Champion \& Seth (1968) (see Table 3). Finally, maps of the potential distributions of slender loris subspecies were compared with overlays of the protected area boundaries.

\section{RESULTS}

In each of 4 replicate validations of slender loris model predictions, a different set of about $25 \%$ occurrence points were available for testing model predictions. For each replicate, we calculated binomial probabilities at each of the 10 predictive levels; in all cases (4 replicate tests $\times 10$ predictive levels each), agreement between test occurrence points and model predictions was significantly better than random (binomial tests, all $p<0.05$ ). This success in predicting independent tests of occurrence data gave confidence in model accuracy; as a result, we used all available points to develop final models (Fig. 1).

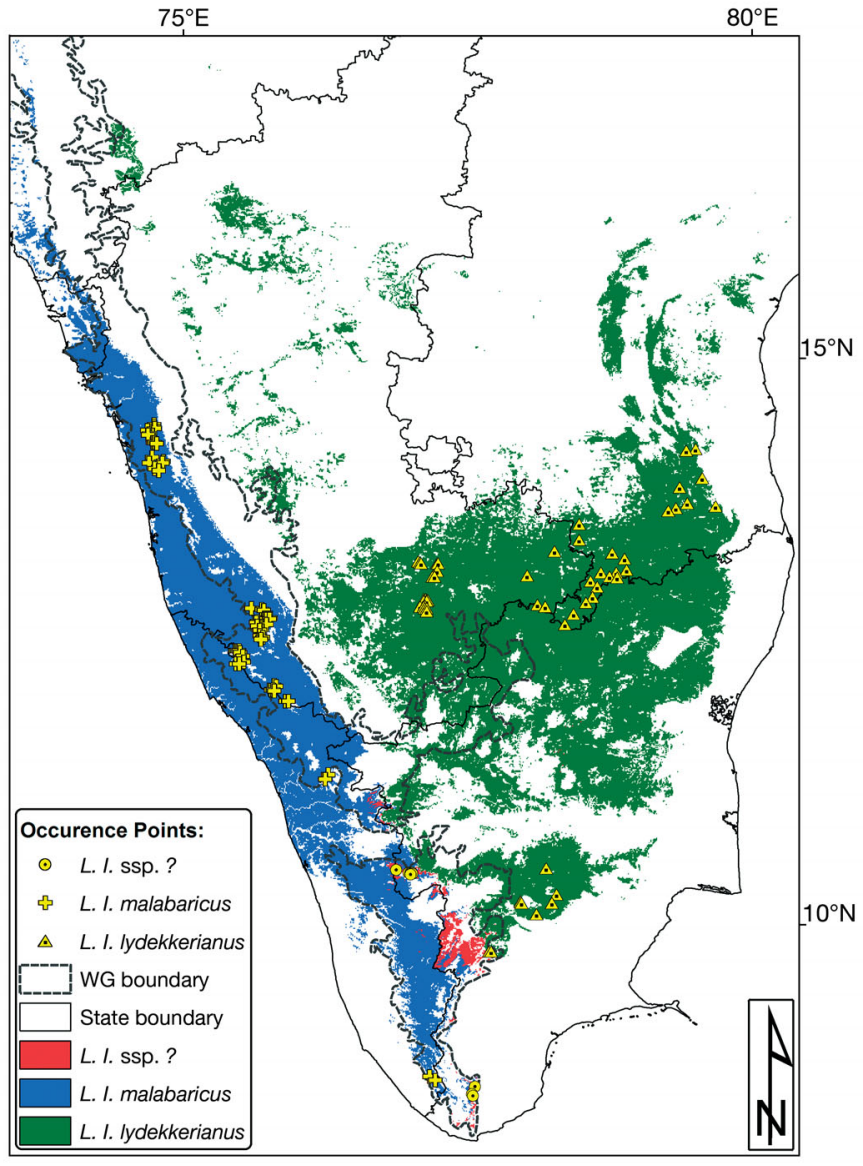

Fig. 1. Loris lydekkerianus sspp. Points of known occurrence and modeled potential distributions of slender loris subspecies in peninsular India. WG: Western Ghats. Modeled potential distributions are given in red for the unidentified $L$. $l$. ssp. (L. 1. ssp. ?), blue for L. 1. malabaricus and green for L. 1. lydekkerianus

The potential distribution of Loris lydekkerianus lydekkerianus occupies a large geographical tract of drier forest patches and human-dominated landscapes spread across the rain shadow areas of peninsular India. The potential distribution of L. 1. malabaricus extends over a relatively smaller geographic range and shows no overlap with L. l. lydekkerianus. It tends to be confined to the western side of the Western Ghats, a region dominated by wetter climate, receiving summer (June to September) rainfall through southwest monsoons. The potential distribution of L. l. ssp. ? appears to occupy a patchy geographic range distributed along the eastern foothills of the southern Western Ghats, a region typically known for its intermediate climate, receiving winter rains (October to December) from the retreating northeast monsoons (Gunnell 1997, McGinley 2007). (Figs. 1 \& 2a)

Slender lorises appear to be better adapted to broad altitudinal and precipitation ranges compared to the 

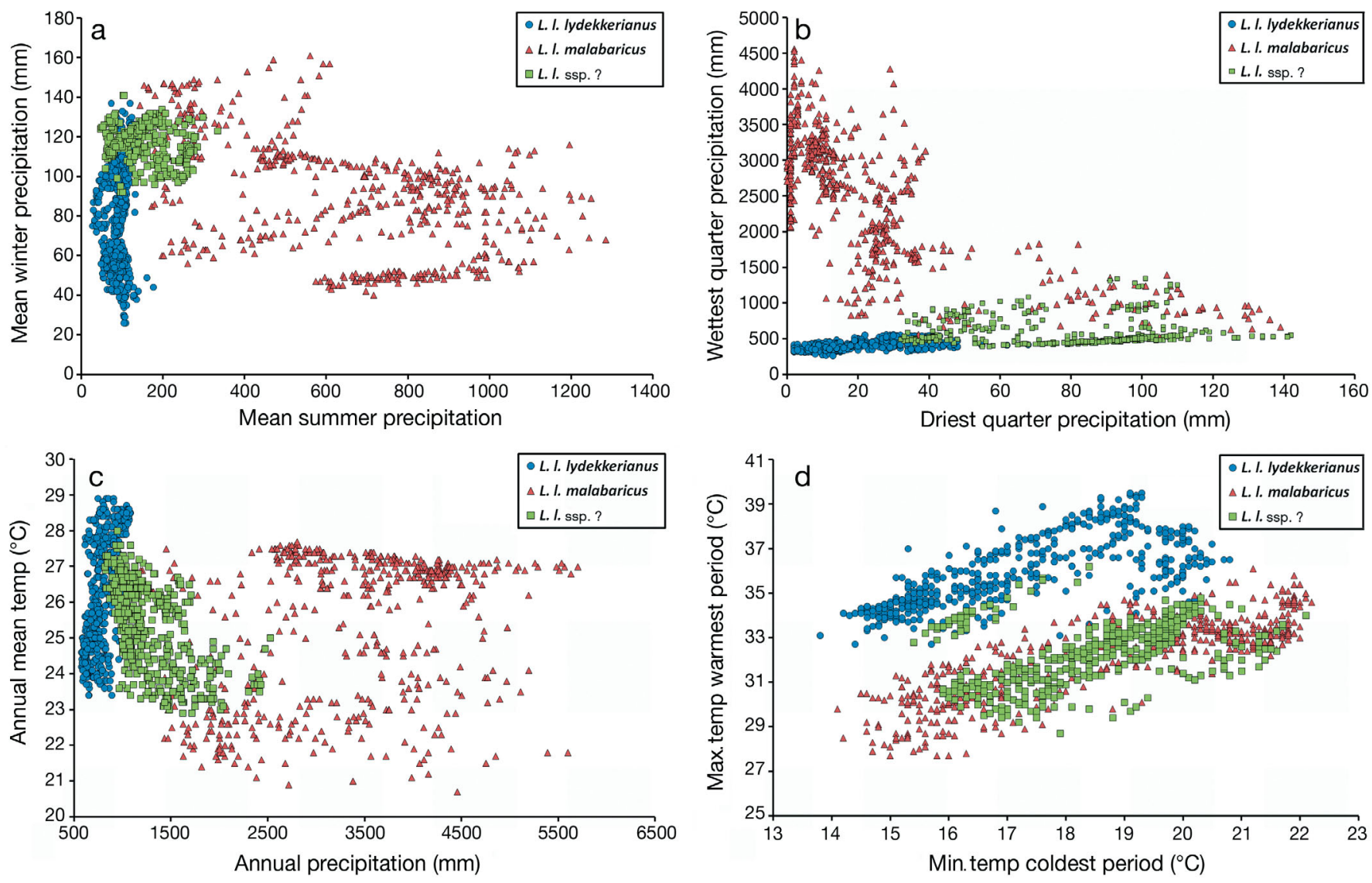

Fig. 2. Loris lydekkerianus sspp. Ecological niches of the modeled potential distributions of slender loris subspecies in peninsular India with respect to precipitation and temperature. (a) Mean winter (October to January) vs. mean summer (June to September) precipitation, (b) precipitation of the wettest vs. driest quarters, (c) annual mean temperature vs. annual precipitation, and (d) maximum temperature of the warmest period vs. minimum temperature of the coldest period. $L$. 1 . ssp. ?: unidentified $L$. 1 . ssp.

other micro-endemic species found within Western Ghats. Results show little difference between the altitudinal ranges of modeled potential distributions for the 3 slender loris subspecies, with Loris lydekkerianus malabaricus attaining the maximum altitude of about $1500 \mathrm{~m}$ above sea level (m a.s.l.). The precipitation range and its temporal pattern demonstrate marked variation within the regions of potential distribution for each subspecies (Table 2, Fig. 2). The potential distribution of L. 1. ssp. ? occupies a distinct intermediate precipitation zone with an average annual precipitation of about $1500 \mathrm{~mm}$ as compared to about $800 \mathrm{~mm}$ for $L$. $l$. lydekkerianus and about $3500 \mathrm{~mm}$ for L. 1. malabaricus. The L. 1. ssp. ? zone receives intermediate average rainfall during both winter and summer monsoons compared to the zones of the 2 known subspecies (Table 2, Fig. 2). A closer look at the binary plots reveals that the modeled niches for all 3 subspecies dominate distinct regions within the binary spaces, showing only a slight overlap (Fig. 2).

There is fair correspondence between the types of forests actually used by slender lorises and regions of

Table 2. Loris lydekkerianus sspp. Potential distribution across elevation (m above sea level, m a.s.l.) and precipitation ranges. L. 1. ssp. ?: unidentified L. l. ssp.

\begin{tabular}{|c|c|c|c|c|c|c|}
\hline \multirow[t]{2}{*}{ Species } & \multicolumn{3}{|c|}{ _ Elevation (m a.s.l.) } & \multicolumn{3}{|c|}{ — Precipitation (mm) } \\
\hline & Min. & Max. & Average & Min. & Max. & Average \\
\hline L. l. lydekkerianus & 21 & 1080 & 551 & 510 & 1150 & 830 \\
\hline L. 1. malabaricus & 1 & 1493 & 747 & 940 & 6090 & 3515 \\
\hline L. l. ssp.? & 153 & 1190 & 672 & 910 & 2200 & 1555 \\
\hline
\end{tabular}


Table 3. Forest type under (a) points of known occurrence and (b) regions of potential distribution of Loris lydekkerianus sspp. Global landcover classes are based on Hansen et al. $(1998,2000)$. Forest type equivalents are based on Champion \& Seth (1968).

$$
\text { L. 1. ssp. ?: unidentified L. I. ssp. }
$$

\begin{tabular}{|c|c|c|c|c|c|c|c|}
\hline Global landcover classes & Forest type equivalents & \multicolumn{2}{|c|}{$\begin{array}{l}\text { L. 1. lydekkerianus } \\
\text { Occurrence Area (\%) }\end{array}$} & \multicolumn{2}{|c|}{ L. 1. malabaricus } & \multicolumn{2}{|c|}{$\begin{array}{c}\text { L. l. ssp. ? } \\
\text { Occurrence Area (\%) }\end{array}$} \\
\hline \multicolumn{8}{|c|}{ (a) Points of known occurrence } \\
\hline Broadleaf evergreen & Evergreen & 0 & 0 & 6 & 11.3 & 0 & 0 \\
\hline Broadleaf deciduous & Deciduous (wet/dry) & 0 & 0 & 1 & 1.9 & 1 & 8.3 \\
\hline Woodland scrub & Scrub (wet/dry) ${ }^{\mathrm{a}}$ & 13 & 22.4 & 39 & 73.6 & 8 & 66.7 \\
\hline Wooded grassland & Degraded scrub & 10 & 17.2 & 6 & 11.3 & 0 & 0 \\
\hline Closed shrubland & Tropical thorn & 2 & 3.4 & 0 & 0 & 1 & 8.3 \\
\hline Cropland/grassland & Agriculture/grassland & 33 & 56.9 & 1 & 1.9 & 2 & 16.7 \\
\hline Total & & 58 & 100 & 53 & 100 & 12 & 100 \\
\hline \multicolumn{8}{|c|}{ (b) Regions of potential distribution } \\
\hline Broadleaf evergreen & Evergreen & 13 & 0 & 1124 & 2 & 11 & 1 \\
\hline Broadleaf deciduous & Deciduous (wet/dry) & 13436 & 13 & 24914 & 51 & 721 & 42 \\
\hline Woodland scrub & Scrub (wet/dry) ${ }^{\mathrm{a}}$ & 31373 & 30 & 20859 & 43 & 387 & 23 \\
\hline Wooded grassland & Degraded scrub & 15357 & 36 & 1308 & 3 & 364 & 21 \\
\hline Closed shrubland & Tropical thorn & 36797 & 15 & 85 & 0 & 25 & 1 \\
\hline Cropland/grassland & Agriculture/grassland & 6329 & 6 & 422 & 1 & 206 & 12 \\
\hline Total & & 103306 & 100 & 48713 & 100 & 1714 & 100 \\
\hline
\end{tabular}

modeled potential distribution (Table 3). Sightings from patchy human-dominated landscapes (especially in the case of Loris lydekkerianus lydekkerianus), scrub forest and agricultural regions (orchards/plantations) appear to dominate the locations of actual occurrences. Regions of modeled potential distribution reveal, however, that scrub (wet and dry), degraded scrub (open) and deciduous forest types dominate the potential distribution of slender loris subspecies. Despite the coarse spatial resolution (30 arc seconds) of the data, results are consistent with previous fieldbased studies (Singh et al. 1999, 2000, Kumara et al. 2006, Nekaris \& Bearder 2007). While the modeled distribution of L. l. lydekkerianus suggests a preference for drier and open forest types, L. 1. malabaricus is expected to favor more moist and open forests and $L$. $l$. ssp. ? with almost always choose the intermediate forest types ranging between the drier and moister classes.

We provide geographic estimates of the modeled potential distribution of all 3 slender loris subspecies across the administrative limits of the states of Andhra
Pradesh, Karnataka, Tamil Nadu, Goa and Maharashtra (Fig. 1, Table 4). The modeled potential distribution of Loris lydekkerianus lydekkerianus covers a wide array of forest types extending up to the Eastern Ghats. Its distribution in Andhra Pradesh remains within the forests of the hill system of the south and eastern part of the state. In Karnataka, its distribution is mainly restricted to the southeastern part of the state, away from the wet forests of the Western Ghats, whereas in Tamil Nadu its distribution is nearer the foothills of the Western Ghats (Fig. 1, Table 4). The modeled potential distribution of L. 1. malabaricus follows the western flanks of the Western Ghats, cutting across the Malabar Coast through the states of Kerala and Karnataka, marginally spreading over to Tamil Nadu and extending as far north as the moister forests of Goa and Maharashtra (Fig. 1, Table 4). The potential distribution of $L$. l. ssp. ? remains largely confined to patchy habitats found along the eastern slopes of the southern Western Ghats within the administrative limits of Tamil Nadu and Kerala. Until now there was no record of L. l. ssp. ? from the Nilgiris, a region in the north of

Table 4. Loris lydekkerianus sspp. Modeled potential distribution across different states of peninsular India. Values given are potential geographic ranges (\% total potential distribution). L. l. ssp. ?.: unidentified L. l. ssp. ?; -: no area predicted in modeled potential distribution

\begin{tabular}{|lcccccc|}
\hline Species & Maharashtra & Goa & Karnataka & Kerala & Tamil Nadu & Andhra Pradesh \\
\hline L. l. lydekkerianus & $808(1 \%)$ & - & $35413(34 \%)$ & $15(0 \%)$ & $46191(45 \%)$ & $20879(20 \%)$ \\
L. l. malabaricus & $1352(3 \%)$ & $1859(4 \%)$ & $20386(42 \%)$ & $22490(46 \%)$ & $2626(5 \%)$ & - \\
L. l. ssp. ? & - & - & - & $190(11 \%)$ & $1524(89 \%)$ & - \\
\hline
\end{tabular}


Palghat Gap, but our model predicts a strong potential for it to occur in this region; further investigation of the distribution of this undescribed subspecies is therefore warranted.

\section{DISCUSSION}

The classification of slender lorises has been conventionally based on the comparison of museum specimens (Bearder 1999), which has remained a difficult task owing to the small number of available samples. The distribution maps of such species, prepared mainly from the descriptions of the locations found with the museum specimens, also remain crude. Longterm and detailed studies on species within primate groups including Tarsiiformes, Lemuriformes, Galaginae and Aoutidae have revealed that the actual numbers of these species are highly underestimated, which has led to wide-spread acceptance of newer species and/or subspecies and frequent taxonomic rearrangements (Masters 1988, Zimmermann et al. 1988, Bearder et al. 1995, Martin 1995, Hafen et al. 1998, Nietsch 1999, Pastorini et al. 2003, Nekaris \& Jaffe 2007). Many of these species, formerly thought to be broadly distributed, are now considered to be confined to more restricted ranges (Ganzhorn et al. 1997). Nekaris \& Bearder (2007) suspect similar trends for the Lorisinae, the lorises of Asia. Due to insufficient knowledge regarding the morphological differences between many species and/or subspecies of Lorisinae (e.g. species belonging to Nycticebus in Sundaland; Nekaris \& Jaffe 2007), we expect a similar situation in southern India. For example, Loris lydekkerianus malabaricus was distinguished from other subspecies based on only 4 specimens including 2 immature animals. Osman-Hill (1933) also noted some confusion regarding the localities of collected specimens and their taxonomic status; no recent attempts have been made to collect L. 1. malabaricus specimens and verify their taxonomic status. L. 1. malabaricus was thought to be distributed throughout the forests of the entire Western Ghats (Devaraj Sarkar et al. 1981, Schulze \& Meier 1995), a distribution questioned by Kumara et al. (2006) based on recently extended surveys (Kumar et al. 2002, 2006). The modeled potential distribution from the present study, using all the available known locations, further indicates that this subspecies' distribution may not be as extensive as once thought.

The known populations and modeled potential distributions of Loris lydekkerianus lydekkerianus and $L$. 1. malabaricus do not overlap, and there is $<0.1 \%$ overlap of the 2 known subspecies with the modeled potential distribution of L. 1 . ssp. ?, indicating a clear difference in their modeled ecological niches (Fig. 1). This reinforces the doubts (Nekaris \& Jaffe 2007) raised about earlier projections of slender loris distribution in south India. The present study supports the distinction of a third population of slender loris that is distinct in morphology and habitat requirements from the 2 known subspecies. The fact that $L$. 1 . ssp. ? is found in the rain shadow areas along the eastern slopes of the Western Ghats prompted us to attempt a separate modeling effort for this subspecies with a clear intention to investigate if its current ecological conditions overlapped with the other 2 known subspecies. The rain shadow areas along the eastern sides of the Nilgiris and the southern Western Ghats are characterized by a prevailing dry climate and dominated by deciduous and, at times, scrub forests (Pascal 1988). Results indicate that L. 1 . ssp. ? occupies a narrow, geographically restricted niche, largely within the drier forests, yet it has little overlap with the 2 known subspecies. It is important to note that almost the whole of its modeled niche (about $99 \%$ ) falls within the limits of the Western Ghats.

Our survey (Kumara et al. 2006) did not detect slender lorises in the northern and central plains of Karnataka, despite model predictions showing environmental conditions in those areas similar to other locations with known occurrences of slender lorises. Further investigation is required to discover whether slender lorises historically occurred in these regions of potential distribution. There is a possibility that, despite the availability of suitable environmental conditions, slender lorises may not be present as a result of various factors that might be affecting their presence in time and space (Prasad et al. 1978, Karanth 1986, Ceballos \& Brown 1995, Kumara et al. 2006, Kumara \& Raj 2007).

The limited records of actual species distribution may neither fully capture the species' ecological niche nor their realized niches. This could result in a possible under-representation of the actual distribution or, equally, an over-prediction of the part of the ecological niche not utilized by the species. Modeled distributions reconstructed from known occurrences thus fall somewhere between the true ecological niche and the realized niche (Singh et al. 1999, 2000, Kumar et al. 2002, 2006, 2009), and point to possible areas for further exploration to fill the gap in our knowledge of species distributions.

Analysis of species occurrence and protected area distribution indicates that all 3 subspecies are only marginally protected (Fig. 3). It is important to highlight that Loris lydekkerianus lydekkerianus, with $<1 \%\left(1029 \mathrm{~km}^{2}\right)$ of its modeled distribution falling within protected areas, is vulnerable in the face of growing anthropogenic pressures. The issue of its conservation becomes complicated as the species is thriving even in human-dominated landscapes within very 


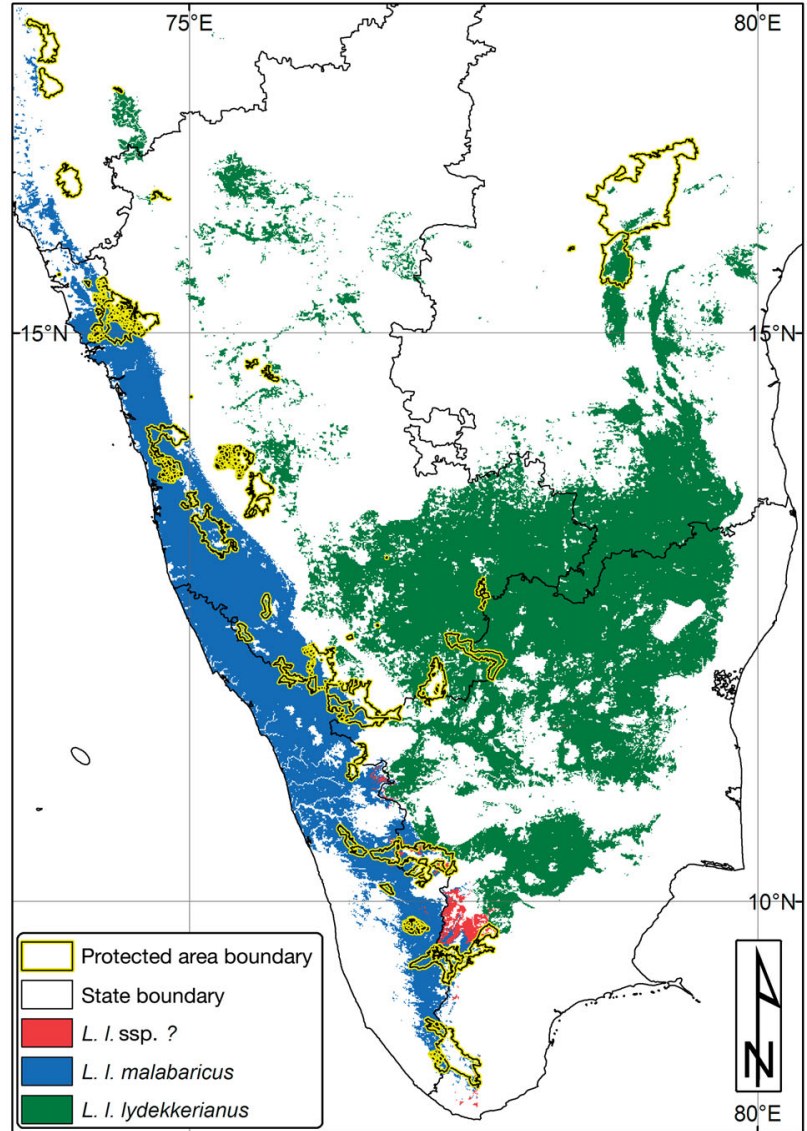

Fig. 3. Protected area network and loris distribution

small islands of habitat or within plantations that may not qualify as proper refuge for the species to ensure its future survival. About $12 \%\left(6032 \mathrm{~km}^{2}\right)$ of the modeled distributions of L. 1. malabaricus and about $23 \%$ $\left(398 \mathrm{~km}^{2}\right)$ of L. 1. ssp. ? appear to occur within the confines of protected areas, which may be insufficient for the long-term conservation of the species, despite its ability to survive within disturbed landscapes (Singh et al. 1999, 2000, Nekaris 2000, Kumara et al. 2006).

\section{CONCLUSIONS}

This is the first attempt to model the potential distribution of stealthy, hard to detect and extremely shy subspecies of slender lorises reported from southern peninsular India. It has been possible to produce a rational and objective map of their potential distribution that indicates a hitherto undescribed subspecies. Our motivation was to develop a model-based framework for future sampling and to assess the conservation status of distinct populations to help plan systematic conservation strategies in the face of growing threats from urbanization-linked land cover changes and habitat loss. Our results of modeled potential niches point to a morphologically distinct new subspecies occupying an area with different vegetation and environmental conditions compared to the 2 known subspecies. Based on the results of the present study, we recommend a systematic molecular study at the population level to establish the status of the different morphotypes. One of the main contributions of the present study is the generation of the first map detailing the modeled potential distributions of the slender loris subspecies based on objective criteria, which can be dynamically updated with growing knowledge.

Acknowledgements. The authors thank Prof. M. Singh, M. Chaitra, A. Singh, N. Lele and K. A. Subramaniam for helpful comments, discussion and support at various stages of this work. The authors also acknowledge the significant contribution from the anonymous reviewer in improving the text. Financial support for fieldwork was provided by the Rufford Maurice Laing Foundation, the American Society of Primatologists and the Department of Science and Technology, Government of India. The Ashoka Trust for Research in Ecology and Environment (ATREE, www.atree.org), the Indo-US Science and Technology Forum and the JRS Foundation provided support for the modeling effort.

\section{LITERATURE CITED}

Anderson RP, Lew D, Peterson AT (2003) Evaluating predictive models of species distributions: criteria for selecting optimal models. Ecol Model 162:211-232

> Austin MP, Nicholls AO, Margules CR (1990) Measurement of the realized qualitative niche: environmental niches of five Eucalyptus species. Ecol Monogr 60:161-177

Baillie JEM, Hilton-Taylor C, Stuart SN (eds) (2004) 2004 IUCN Red List of Threatened Species. A global species assessment. IUCN, Gland and Cambridge

Balmford A, Crane P, Dobson AP, Green RE, Mace GM (2005) 2010 challenge: data availability, information needs and extraterrestrial rights. Philos Trans R Soc Lond B Biol Sci 360:221-228

> Bearder SK (1999) Physical and social diversity among nocturnal primates: a new view based on long-term research. Primates 40:267-282

Bearder SK, Honess PE, Ambrose L (1995) Species diversity among galagos with special reference to mate recognition. In: Alterman L, Doyle GA, Izard MK (ed) Creatures of the dark: the nocturnal prosimians. Plenum, New York, p 331-352

Berry PM, Dawson TP, Harrison PA, Pearson RG (2002) Modelling potential impacts of climate change on the bioclimatic envelope of species in Britain and Ireland. Glob Ecol Biogeogr 11:453-462

Blandford WT (1888) Mammals of British India. Taylor \& Francis, London

Bourg NA, McShea WJ, Gill DE (2005) Putting a CART before the search: successful habitat prediction for a rare forest herb. Ecology 86:2793-2804

Butchart SHM, Stattersfield AJ, Bennun LA, Shutes SM and others (2004) Measuring global trends in the status of biodiversity: Red List indices for birds. PLoS Biol 2:e383 
Ceballos G, Brown JH (1995) Global patterns of mammalian diversity, endemism, and endangerment. Conserv Biol 9: 559-568

Champion HG, Seth SK (1968) A revised classification of the forest types of India. Natraj Publishers, Dehradun

Csuti B (1996) Mapping animal distribution areas for gap analysis. In: Scott JM, Tear TH, Davis FW (eds) Gap analysis: a landscape approach to land management issues. American Society of Photogrammetry and Remote Sensing, Bethesda, MD, p 135-145

Devaraj Sarkar HB, Murali S, Prasad DT, Shekarappa BM, Vijayalakshmi V (1981) The population and distribution of the slender loris (Loris tardigradus) in Karnataka State. Tigerpaper 8:7-10

Eidenshink JC, Faundeen JL (1994) The 1 km AVHRR global land data set: first stages in implementation. Int J Remote Sens 15:3443-3462

Fiedler W (1956) Übersicht über das System der Primaten. In: Hofer H, Schulze AH, Starck D (eds) Primatologia 1. S. Karger Verlag, Basel, p 321-351

Ganzhorn JU, Rakotosamimanana B, Hannah L (1997) Priorities for biodiversity conservation in Madagascar. Primate Rep 48:1-81

> Gottfried M, Pauli H, Reiter K, Grabherr G (1999) A finescaled predictive model for changes in species distribution patterns of high mountain plants induced by climate warming. Divers Distrib 5:241-251

Grinnell J (1917) Field tests of theories concerning distributional control. Am Nat 51:115-128

Groves CP (2001) Primate taxonomy. Smithsonian Institution Press, Washington, DC

Gunnell Y (1997) Relief and climate in South Asia: the influence of the Western Ghats on the current climate pattern of peninsular India. Int J Climatol 17:1169-1182

Hafen T, Neveu H, Rumpler Y, Wilden I, Zimmerman E (1998) Acoustically dimorphic advertisement calls separate morphologically and genetically homogenous populations of the grey mouse lemur (Microcebus murinus). Folia Primatol 69:342-356

Hansen MC, DeFries RS, Townshend JRG, Sohlberg R (1998) $1 \mathrm{~km}$ land cover classification derived from AVHRR, Version 1.0. The Global Land Cover Facility, University of Maryland, College Park, MD

Hansen MC, DeFries RS, Townshend JRG, Sohlberg R (2000) Global land cover classification at $1 \mathrm{~km}$ resolution using a decision tree classifier. Int J Remote Sens 21:1331-1365

> Hernandez PA, Graham CH, Master LL, Albert DL (2006) The effect of sample size and species characteristics on performance of different species distribution modeling methods. Ecography 29:773-785

Hijmans RJ, Cameron SE, Parra JL, Jones PG, Jarvis A (2005) Very high resolution interpolated climate surfaces for global land areas. Int J Climatol 25:1965-1978

Holt RD, Gaines MS (1992) Analysis of adaptation in heterogeneous landscapes: implications for the evolution of fundamental niches. Evol Ecol 6:433-447

Jenkins PD (1987) Catalogue of primates in the British Museum (Natural History). Part IV. Suborder Strepsirrhini. British Museum (Natural History), London

Johnson JM (1984) Diurnal activities of the slender loris, Loris tardigradus, in the Mundanthurai Sanctuary, Tamil Nadu (India). In: Roonwal ML, Mohnot SM, Rathore NS (eds) Current primate researches. University of Jodhpur Press, Jodhpur, p 389-395

Karanth KU (1986) Status of wildlife and habitat conservation in Karnataka. J Bombay Nat Hist Soc 83:166-179

Kinnaird MF, Sanderson EW, O'Brien TG, Wibisono HT, Woolmer G (2003) Deforestation trends in a tropical land- scape and implications for endangered large mammals. Conserv Biol 17:245-257

Kumar MA, Singh M, Srivastava S, Udhayan A, Kumara HN, Sharma AK (2002) Distribution and management of wild mammals in Indira Gandhi Wildlife Sanctuary, Tamil Nadu, India. J Bombay Nat Hist Soc 99:184-210

Kumara HN (2005) An ecological assessment of mammals in non-sanctuary areas of Karnataka. University of Mysore, Mysore

Kumara HN (2007) Impact of local hunting on abundance of large mammals in three protected areas of the Western Ghats, Karnataka. Final Technical Report. National Institute of Advance Studies, Bangalore

Kumara HN, Raj VVM (2007) The great Indian bustard (Ardeotis nigriceps): Are they disappearing in Karnataka? J Bombay Nat Hist Soc 104:13-14

Kumara HN, Singh M (2004) The influence of differing hunting practices on the relative abundance of mammals in two rainforest areas of the Western Ghats, India. Oryx 38:321-327

Kumara HN, Singh M, Kumar S (2006) Distribution, habitat correlates and conservation of slender loris (Loris lydekkerianus) in Karnataka, India. Int J Primatol 27:941-969

Kumara HN, Singh M, Irfan-Ullah M, Kumar S (2009) Distribution and conservation status of slender loris in Karnataka, India. Prosimians 2007, Ithala Game Reserve, Louwsberg, KwaZulu-Natal, South Africa, 15-19 Jul 2007 (in press)

Linkie M, Chapron G, Martyr DJ, Holden J, Leader-Williams N (2006) Assessing the viability of tiger subpopulations in a fragmented landscape. J Appl Ecol 43:576-586

Manel S, Dias JM, Buckton ST, Ormerod SJ (1999a) Alternative methods for predicting species distribution: an illustration with Himalayan river birds. J Appl Ecol 36: 734-747

Manel S, Dias JM, Ormerod SJ (1999b) Comparing discriminant analysis, neural networks and logistic regression for predicting species distributions: a case study with a Himalayan river bird. Ecol Model 120:337-347

Manjula A (1984) Changes in levels of proteins in the male reproductive system of the slender loris (Loris tardigradus lydekkerianus). In: Roonwal ML, Mohnot SM, Rathore NS (eds) Current primate researches. University of Jodhpur Press, Jodhpur, p 441-447

Margules CR, Pressey RL (2000) Systematic conservation planning. Nature 405:243-253

Martin RD (1995) Prosimians: from obscurity to extinction. In: Alterman L, Doyle GA, Izard MK (eds) Creatures of the dark: the nocturnal prosimians. Plenum Press, New York, p 535-563

Masters JC (1988) Speciation in the greater galagos (Prosimii: Galaginae): a review and synthesis. Biol J Linn Soc 34: 149-174

McGinley M (2007) South Western Ghats montane rain forests. In: Cutler JC (ed) Encyclopedia of Earth. Environmental Information Coalition, National Council for Science and the Environment, Washington, DC

Miller RI (1994) Mapping the diversity of nature. Chapman \& Hall, London, p 218

Nekaris KAI (2000) The socioecology of the Mysore slender loris (Loris tardigradus lydekkerianus) in Dindigul, Tamil Nadu, South India. Department of Anthropology, Washington University, St. Louis, MO

> Nekaris KAI (2001) Activity budget and positional behaviour of the Mysore slender loris: implications for slow climbing locomotion. Folia Primatol 72:228-241

Nekaris KAI (2003) Spacing system of the Mysore slender loris (Loris lydekkerianus lydekkerianus). Am J Phys Anthropol 121:86-96 
Nekaris KAI, Bearder SK (2007) The strepsirrhine primates of Asia and mainland Africa: diversity shrouded in darkness. In: Campbell C, Fuentes A, MacKinnon K, Panger M, Bearder SK (eds) Primates in perspective. Oxford University Press, Oxford, p 24-45

Nekaris KAI, Jaffe S (2007) Unexpected diversity of slow lorises (Nycticebus spp.) within the Javan pet trade: implications for slow loris taxonomy. Contrib Zool 76:187-196

Nekaris KAI, Rusmussen DT (2003) The diet of the Mysore slender loris (Loris tardigradus lydekkerianus). Int J Primatol 24:33-46

Nietsch A (1999) Duet vocalizations among different populations of Sulawesi tarsiers. Int J Primatol 20:567-583

Nix HA (1986) A biogeographic analysis of Australian elapid snakes. In: Longmore R (ed) Atlas of elapid snakes of Australia, Australian Government Publishing Service, Canberra, p 415

Osman-Hill WC (1933) A monograph on the genus Loris, with an account of the external, cranial and dental characters of the genus: a revision of the known forms, and the description of a new form from northern Ceylon. Ceylon J Sci Ser B 18:89-132

Pascal JP (1988) Wet evergreen forests of the Western Ghats of India: ecology, structure, floristic composition and succession. Institut francais de Pondicherry, Pondicherry

Pastorini J, Thalmann U, Martin RD (2003) A molecular approach to comparative phylogeography of extant Malagasy lemurs. Proc Natl Acad Sci USA 100:5879-5884

Pearson RG, Raxworthy C, Nakamura M, Peterson AT (2007) Predicting species' distributions from small numbers of occurrence records: a test case using cryptic geckos in Madagascar. J Biogeogr 34:102-117

Peterson AT (2005) Kansas gap analysis: the importance of validating distributional models before using them. Southwest Nat 50:230-236

Peterson AT, Kluza DA (2003) New distributional modelling approaches for gap analysis. Anim Conserv 6:47-54

Peterson A, Papes M, Kluza D (2003) Predicting the potential invasive distributions of four alien plant species in North America. Weed Sci 51:863-868

Phillips SJ, Dudik M, Schapire RE (2004) A maximum entropy approach to species distribution modeling. Proc 21st Century Int Conf Machine Learning, ACM Press, New York, p 655-662

Prasad SN, Nair VP, Sharathchandra H, Gadgil M (1978) On factors governing the distribution of wild mammals in Karnataka. J Bombay Nat Hist Soc 75:409-411

Radhakrishna S, Singh M (2002a) Activity schedule and habitat use of slender loris (Loris tardigradus lydekkerianus). J Bombay Nat Hist Soc 99:400-407

Radhakrishna S, Singh M (2002b) Home range and ranging pattern in the slender loris (Loris tardigradus lydekkerianus). Primates 43:237-248

Radhakrishna S, Singh M (2002c) Social behavior of slender loris (Loris tardigradus lydekkerianus). Folia Primatol 73:181-196

Radhakrishna S, Singh M (2004a) Infant development in the slender loris (Loris lydekkerianus lydekkerianus). Curr Sci 86:1121-1127

Radhakrishna S, Singh M (2004b) Reproductive biology of the slender loris (Loris lydekkerianus lydekkerianus). Folia Primatol 75:1-13

Ramaswami LA, Kumar TCA (1962) Reproductive cycle of the slender loris. Naturwissenschaften 49:115-116

Rao P (1994) Occurrence of the slender loris (Loris tardigradus) in South Coastal Andhra Pradesh, India. J Bombay Nat Hist Soc 91:303
Raxworthy CJ, Martínez-Meyer E, Horning N, Nussbaum RA, Schneider GE, Ortega-Huerta MA, Peterson AT (2003) Predicting distributions of known and unknown reptile species in Madagascar. Nature 426:837-841

Roonwal ML, Mohnot SM (1977) Primates of South Asia: ecology, sociobiology and behavior. Harvard University Press, Cambridge, MA

Ryley KV (1913) Mammal survey of India: Loris lydekkerianus, Cabrera. The Mysore slender loris. J Bombay Nat Hist Soc 22:283-287

Sarma R, Kadam M (1984) Study of germ-cell morphology and the spermatogenic cycle in the slender loris, Loris tardigradus lydekkerianus (Cabr.). In: Roonwal ML, Mohnot SM, Rathore NS (eds) Current primate researches. University of Jodhpur Press, Jodhpur, p 167-175

Schulze H, Meier B (1995) The subspecies of Loris tardigradus and their conservation status: a review. In: Alterman L, Doyle GA, Izard MK (eds) Creatures of the dark: the nocturnal prosimians. Plenum Press, New York, p 193-210

Schulze H, Ramanathan A, Fitch-Snyder H, Nekaris KAI, Singh M, Kaumanns W (2005) Care of rescued south Indian lorises with guidelines for hand-rearing infants. In: Menon V, Ashraf NVK, Panda P, Mainkar K (eds) Back to the wild: studies in wildlife rehabilitation. Wildlife Trust of India, New Delhi, p 104-118

Scott JM, Heglund PJ, Haufler JB, Morrison M, Raphael MG, Wall WB, Samson F (2002) Predicting species occurrences: issues of accuracy and scale. Island Press, Washington, DC

Seth PK (1963) Preliminary observations on slender lorises. Anthropologist 7:45-51

Singh M, Lindburg DG, Udhayan A, Kumar MA, Kumara HN (1999) Status survey of slender loris (Loris tardigradus lydekkerianus) in Dindigul, Tamil Nadu, India. Oryx 33: $30-36$

Singh M, Kumar MA, Kumara HN, Mohnot SM (2000) Distribution and conservation of slender lorises (Loris tardigradus lydekkerianus) in southern Andhra Pradesh, South India. Int J Primatol 21:721-730

- Stockwell DRB, Noble IR (1992) Induction of sets of rules from animal distribution data: a robust and informative method of data analysis. Math Comput Simul 33:385-390

Stockwell DRB, Peters D (1999) The GARP modeling system: problems and solutions to automated spatial prediction. Int J Geogr Inf Sci 13:143-158

Stockwell DRB, Peterson AT (2002) Controlling bias in biodiversity data. In: Scott JM, Heglund PJ, Morrison ML (eds) Predicting species occurrences: issues of scale and accuracy. Island Press, Washington, DC, p 537-546

Swayamprabha MS, Kadam KM (1980) Mother-infant relationship in the slender loris (Loris tardigradus lydekkerianus). Primates 21:561-566

Tucker K, Rushton SP, Sanderson RA, Martin EB, Blaiklock J (1997) Modeling bird distributions: a combined GIS and Bayesian rule-based approach. Landscape Ecol 12:77-93

USGS (United States Geological Survey) (2001) HYDRO1k elevation derivative database. Available at: http://edcdaac. usgs.gov/gtopo30/hydro/

Walker PA, Cocks KD (1991) HABITAT: a procedure for modelling a disjoint environmental envelope for a plant or animal species. Global Ecol Biogeogr Lett 1:108-118

Wroughton RC (1917) The slender loris of Malabar. J Bombay Nat Hist Soci 25:45

> Zimmermann E, Bearder SK, Doyle GA, Anderson AB (1988) Variations in vocal patterns of Senegal and South African lesser bushbabies and their implications for taxonomic relationships. Folia Primatol 51:87-105

Submitted: April 23, 2008; Accepted: January 9, 2009

Proofs received from author(s): March 30, 2009 